Pesq. Vet. Bras. 35(5):437-442, maio 2015

DOI: $10.1590 /$ S0100-736X2015000500008

\title{
Paratuberculose em bovinos de corte na região Sul do Rio Grande do Sul ${ }^{1}$
}

\author{
Letícia Fiss ${ }^{2}$, Bianca Lemos Santos ${ }^{2}$, Pedro Paulo Feitosa de Albuquerque ${ }^{3}$, Rinaldo \\ Aparecido Mota ${ }^{4}$, Clairton Marcolongo-Pereira ${ }^{5 \dagger}$, Maria de Lourdes Adrien ${ }^{2}$, \\ Mauro P. Soares ${ }^{5}$ e Ana Lucia Schild ${ }^{*}$
}

\begin{abstract}
Fiss L., Santos B.L., Albuquerque P.P.F., Mota R.A., Marcolongo-Pereira C., Adrien M.L., Soares M.P. \& Schild A.L. 2015. [Paratuberculosis in beef cattle in Southern Brazil.] Paratuberculose em bovinos de corte na região Sul do Rio Grande do Sul. Pesquisa Veterinária Brasileira 35(5):437-442. Laboratório Regional de Diagnóstico, Faculdade de Veterinária, Universidade Federal de Pelotas, Campus Universitário s/n, Pelotas, RS 96010-900, Brazil. E-mail: alschild@terra.com.br

The epidemiological, clinical and pathological aspects of paratuberculosis diagnosed in southern Rio Grande do Sul in a beef cattle property are described. Two cattle raised extensively and that presented progressive weight loss and chronic diarrhea were necropsied. The mesenteric lymph nodes were enlarged and edematous. The intestinal mucosa was thickened and wrinkled with cerebroid aspect, especially in the final portion of the ileum, ileocecal valve and cecum. Fragments of the organs were fixed in $10 \%$ formalin, embedded in paraffin, sectioned and stained with hematoxylin and eosin (HE) and Ziehl-Neelsen (ZN). Feces samples were referred to Departamento de Medicina Veterinária, Área de Medicina Veterinária Preventiva da Universidade Federal Rural de Pernambuco, for the cultivation of Mycobacterium avium subsp. paratuberculosis with Löwenstein Jensen for mycobacterial and PCR analysis. Histologically, granulomatous enteritis was observed in the jejunum, ileum, cecum and rectum, and in multifocal areas the duodenum and colon. Lymphangitis and granulomatous adenitis was also observed. In ZN staining numerous resistant acid-fast bacilli (AFB) within macrophages, giant cells of Langhans and mesenteric lymph nodes in the jejunum, ileum cecum and rectum were observed. There was no bacterial growth in stool samples. Five samples amplified the gene sequence IS900 specific for Mycobacterium avium subsp. paratuberculosis. It can be concluded that paratuberculosis, despite the few reports, occurs in beef cattle raised extensively in southern Rio Grande do Sul, Paratuberculosis may have a higher prevalence in the region than it is assumed. There is need for diagnosis of this disease and to assume effective measures for its control, as for many it is still considered an exotic malady in Brazil.
\end{abstract}

INDEX TERMS: Paratuberculosis, Mycobacterium avium subsp. paratuberculosis, cattle, PCR.

\footnotetext{
${ }^{1}$ Recebido em 15 de março de 2015.

Aceito para publicação em 9 de maio de 2015.

${ }^{2}$ Pós-Graduandos em Medicina Veterinária, Faculdade de Veterinária (FV), Universidade Federal de Pelotas (UFPel), Campus Universitário s/n, Pelotas, RS 96010-900, Brasil.

${ }^{3}$ Programa de Pós-Graduação em Ciência Veterinária, Universidade Federal Rural de Pernambuco (UFRPE), Rua Dom Manuel de Medeiros s/n, Dois Irmãos, Recife, PE 52171-900, Brasil.

${ }^{4}$ Departamento de Medicina Veterinária, Área de Medicina Veterinária Preventiva, UFRPE, Rua Dom Manuel de Medeiros s/n, Dois Irmãos, Recife, PE 52171-900.

${ }^{5}$ Laboratório Regional de Diagnóstico, FV-UFPel, Campus Capão do Leão, RS 96010-900, Brasil. *Autor para correspondência: alschild@terra.com.br
}

RESUMO.- Descrevem-se os aspectos epidemiológicos e clínico-patológicos de paratuberculose diagnosticada no sul do Rio Grande do Sul em uma propriedade de bovinos de corte. Dois bovinos criados extensivamente que apresentavam emagrecimento progressivo e diarreia crônica foram necropsiados. Os linfonodos mesentéricos estavam aumentados e edematosos. A mucosa do intestino estava espessada e enrugada com aspecto cerebroide principalmente na porção final do íleo, válvula íleo-cecal e ceco. Fragmentos dos órgãos foram fixados em formalina $10 \%$, incluídos em parafina, cortados e corados pela técnica de hematoxilina e eosina (HE) e Ziehl-Neelsen (ZN). Fezes 
foram encaminhadas ao Departamento de Medicina Veterinária, Área de Medicina Veterinária Preventiva da Universidade Federal Rural de Pernambuco para o cultivo de Mycobacterium avium subsp. paratuberculosis em meio Lowenstein Jensen com micobactina e para realização da PCR. Histologicamente, havia enterite granulomatosa no jejuno, íleo, ceco e reto, afetando multifocalmente, também, o duodeno e o cólon. Havia, ainda, linfangite e adenite granulomatosa. Pela coloração de ZN foram observados numerosos bacilos álcool-ácido resistentes (BAAR) no interior de macrófagos, células gigantes de Langhans e nos linfonodos mesentéricos no jejuno, íleo ceco e reto. Não houve crescimento bacteriano nas amostras de fezes e cinco amostras amplificaram a sequência genética IS900 específica do Mycobacterium avium subesp. paratuberculosis. Pelo presente trabalho pode-se concluir que a paratuberculose apesar dos poucos relatos ocorre também em bovinos de corte criados extensivamente no sul do Rio Grande do Sul e pode ter uma prevalência maior do que se supõe na região. Alerta-se para a necessidade do diagnóstico e da tomada de medidas efetivas de controle para esta doença que, por muitos, ainda é considerada uma doença exótica no Brasil.

TERMOS DE INDEXAÇÃO: Paratuberculose, Doença de Johne, Mycobacterium avium subsp. paratuberculosis, bovinos, PCR.

\section{INTRODUÇÃO}

A paratuberculose, também chamada de doença de Johne, é uma doença infecciosa transmissível caracterizada por enterite granulomatosa que afeta ruminantes e outros mamíferos domésticos e selvagens (Tiwari et al. 2006). É causada por uma bactéria álcool-ácido resistente, Mycobacterium avium subsp. paratuberculosis (Map), que se replica nos macrófagos da lâmina própria do intestino delgado e grosso. A doença caracteriza-se por diarreia crônica e intermitente, emagrecimento progressivo, queda de produção e da fertilidade, principalmente em rebanhos leiteiros, bem como pelo aumento da susceptibilidade a outras infecções (Tiwari et al. 2006).

Paratuberculose causa prejuízos econômicos importantes nas propriedades com gado infectado e é reconhecida como uma das doenças infecciosas mais importantes para a pecuária bovina e de pequenos ruminantes (Huchzermeyer et al. 1994). Mundialmente a prevalência da paratuberculose é maior em bovinos de leite do que em bovinos de corte sendo considerada por alguns autores uma enfermidade do gado de leite (Russel 2011), que é o mais suscetível, devido à criação em ambientes confinados principalmente se estes ambientes são contaminados por fezes (Begg \& Whittington 2008). No Brasil, a paratuberculose tem sido descrita em diversas regiões e em diferentes espécies de ruminantes e os prejuízos econômicos causados por esta enfermidade provavelmente são subestimados, principalmente em rebanhos leiteiros (Yamasaki et al. 2010, 2013). 0 impacto econômico da doença em bovinos de corte também não tem sido estimado (Russel 2011).

Em bovinos as manifestações clínicas são observadas geralmente após três anos de idade (Larsen et al. 1975), porém o Map pode permanecer incubado por um período que pode variar de menos de seis meses até 15 anos, causando sinais clínicos tardios. A maior parte dos casos clínicos ocorre entre três e cinco anos de idade (Chiodini et al. 1984). A infecção em ruminantes ocorre após o nascimento, principalmente pela ingestão de água e alimentos contaminados com fezes, leite ou colostro de animais infectados (Clarke 1997). Pode ocorrer, também, transmissão pela via intra-uterina (Radostits et al. 2007).

O objetivo deste trabalho foi estudar um surto de paratuberculose diagnosticado em bovinos de corte na região Sul do Rio Grande do Sul, descrevendo os aspectos epidemiológicos e clínico-patológicos da doença e detectar por histoquímica a presença de bacilos álcool ácido resistentes em bovinos da propriedade enviados ao abate.

\section{MATERIAL E MÉTODOS}

Foi estudada em uma propriedade da zona Sul do Rio Grande do Sul, no município de Arroio Grande (S32 $0.8^{\prime} 14.6^{\prime \prime}$ e W52 $43^{\circ}$ $31.6^{\prime \prime}$ ) uma enfermidade em bovinos que apresentavam emagrecimento progressivo e diarreia crônica. Os dados epidemiológicos e sinais clínicos da doença foram obtidos junto ao proprietário em visitas à propriedade. Devido à suspeita de paratuberculose, já que outras enfermidades que cursam com diarreia e emagrecimento foram descartadas, foram realizadas necropsias e colheita de material biológico para a confirmação do diagnóstico, que são descritas a seguir.

Estudo da patologia. Os dois bovinos que apresentavam emagrecimento progressivo e diarreia crônica foram eutanasiados e necropsiados tendo em vista o prognóstico desfavorável. Trinta e quatro bovinos da propriedade enviados ao abate foram rastreados no frigorífico coletando-se a porção final do íleo de cada um. Fragmentos de todos os órgãos e sistema nervoso central dos bovinos necropsiados e das amostras de íleo coletadas no frigorífico foram fixados em formalina $10 \%$, incluídos em parafina, cortados com $5 \mu \mathrm{m}$ de espessura e corados pelas técnicas de hematoxilina e eosina (HE) e Ziehl-Neelsen (ZN).

Isolamento bacteriano e PCR IS900. Foram coletadas amostras de fezes da ampola retal de 200 bovinos da propriedade, as quais foram identificadas, congeladas e enviadas ao Departamento de Medicina Veterinária, Área de Medicina Veterinária Preventiva da Universidade Federal Rural de Pernambuco. Dessas 200 amostras 40 foram utilizadas para o cultivo de Map em meio Lowenstein Jensen com micobactina (Klanikova et al. 2012) e caracterização molecular e 34 dessas 40 foram submetidas, também, a PCR.

A extração do DNA foi realizada com o kit de extração Qiamp DNA Stool (Qiagen cat. 51504), conforme instruções do fabricante. Após as extrações dos DNAs, as reações de amplificação foram realizadas em um volume final de $25,0 \mathrm{~mL}$ contendo: $5 \mu \mathrm{L}$ de DNA genômico; $1 \mu \mathrm{L}$ dos primers específicos para IS900 a $10 \mu \mathrm{M}$ (DF: 5'-GACGACTCGACCGCTAATTG-3' e o DR-1: 5'-CCGTAACCGTCATTGTCCAG-3'); 5,5 $\mu \mathrm{L}$ de água Mili-Q ultrapura e 12,5 $\mu \mathrm{L}$ de QuantiFast SYBR Green PCR Kit (mistura para PCR - QIAGEN ${ }^{\circledR}$ ) de acordo com o protocolo do fornecedor. 0 perfil térmico das etapas de reações foi realizado em um termociclador “Rotor-Gene Q" (QIAGEN) com desnaturação inicial a $95^{\circ} \mathrm{C}$ por 5 minutos, seguida de 45 ciclos a $95^{\circ} \mathrm{C}$ por 20 segundos e $60^{\circ} \mathrm{C}$ por 30 segundos. Foi utilizado o software "Rotor-Gene Q Software v1.7" para acompanhar e realizou-se a interpretação dos resultados da qPCR. Para controle positivo e negativo foram utilizadas uma cepa referência de Map e outra de Mycobacterium bovis, respectivamente. 


\section{RESULTADOS}

\section{Epidemiologia e sinais clínicos}

A propriedade onde a doença foi observada era destinada a cria, recria e terminação de bovinos, na grande maioria da raça Angus, os quais eram criados extensivamente em campo nativo. Na propriedade era utilizada inseminação artificial e touros para repasse eram adquiridos em outras propriedades e permaneciam por aproximadamente três anos na propriedade e depois eram substituídos. Os bovinos afetados estavam em um lote de 500 animais em uma área de 640 ha. Os sinais clínicos de diarreia e emagrecimento (Fig.1) com manutenção do apetite foram observados pela primeira vez em um bovino do rebanho em 2009. Posteriormente, em 2012, dois bovinos de dois e quatro anos de idade apresentaram os mesmos sinais clínicos por pelo menos três meses.

\section{Patologia}

Na necropsia os bovinos apresentavam estado corporal ruim (escore 1) e havia completa mobilização das gorduras viscerais. Na abertura da cavidade abdominal, no intestino delgado havia conteúdo líquido a pastoso e, ao corte, a mucosa estava espessada e enrugada, com aspecto anelado ou cerebroide (Figs.2A,B), principalmente na região próxima à válvula íleo-cecal. 0 ceco apresentava, também, espessamento da mucosa (Fig.2B). Os linfonodos mesentéricos estavam aumentados e edematosos com aspecto escuro na
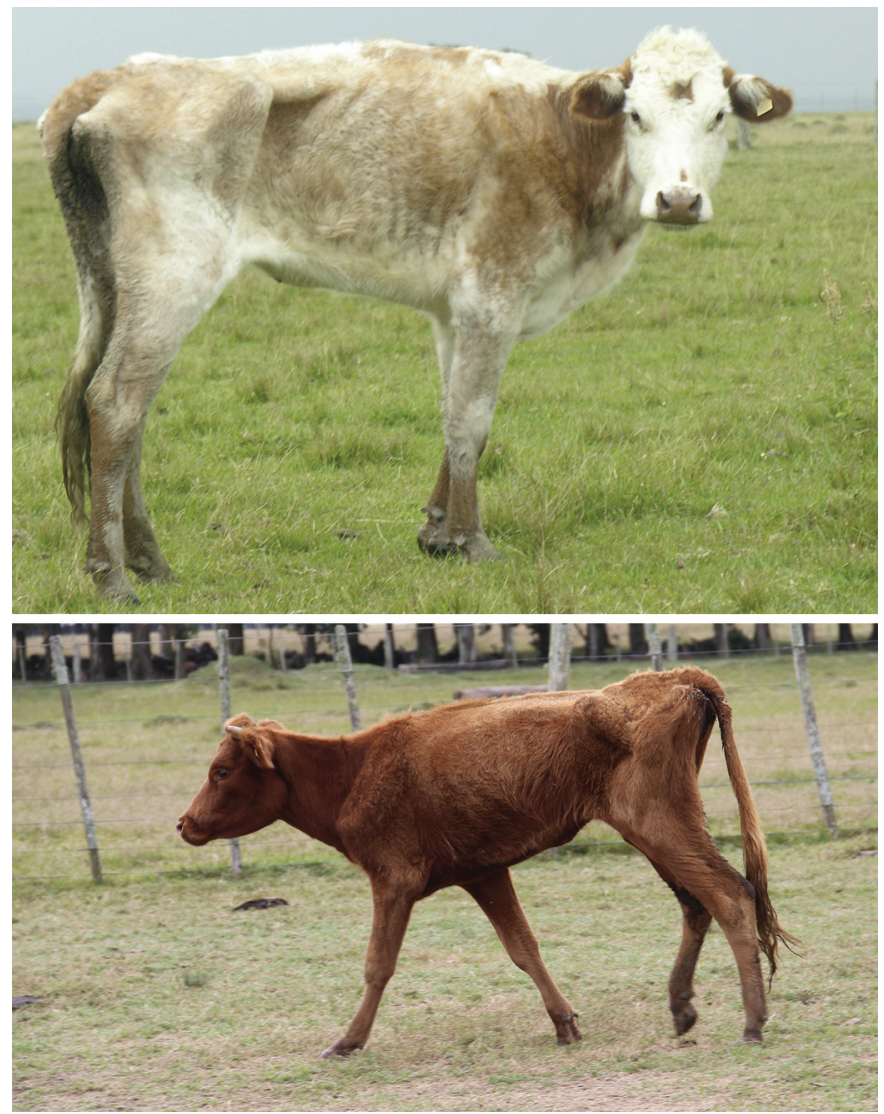

Fig.1. Paratuberculose em bovinos de corte. Bovinos apresentando emagrecimento acentuado (escore corporal 1) e diarreia crônica.
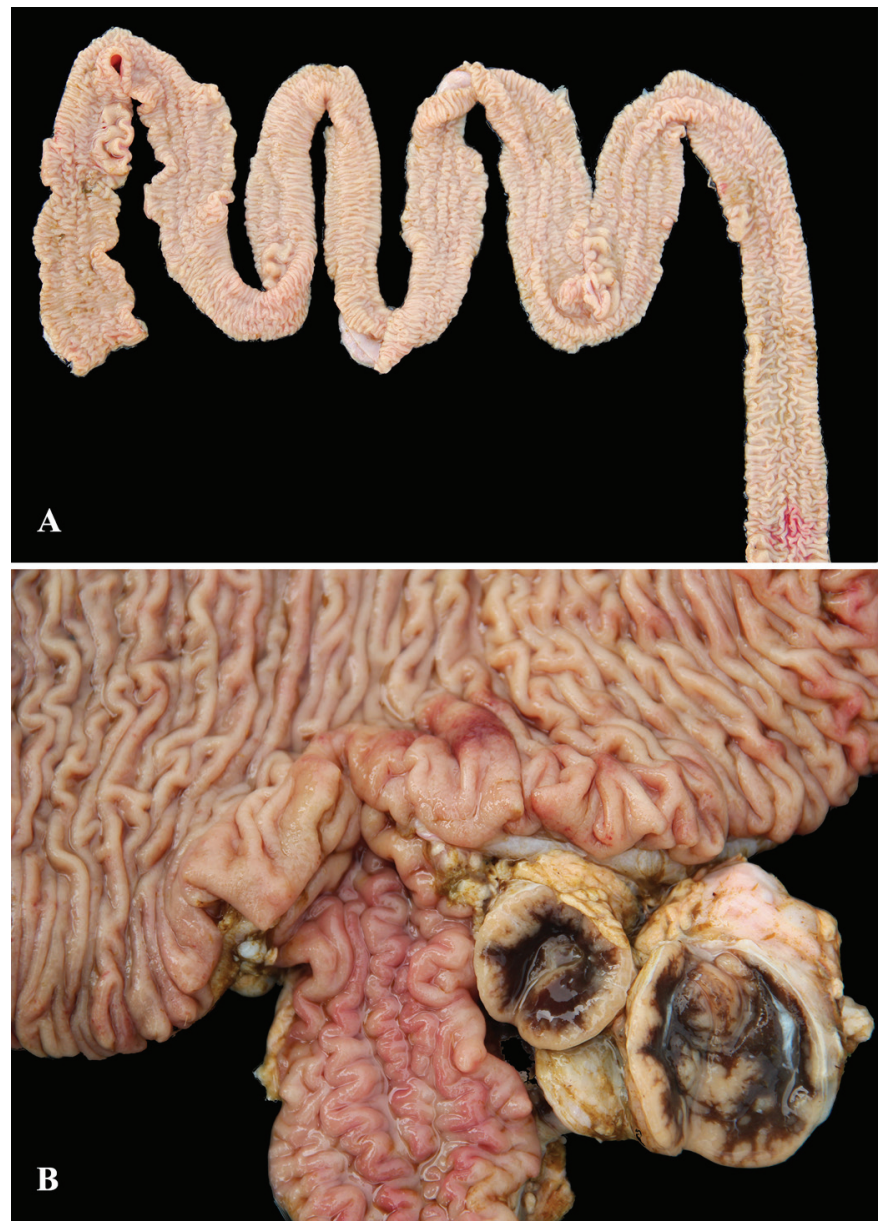

Fig.2. Paratuberculose em bovinos de corte. (A) Intestino delgado (íleo) apresentando espessamento da mucosa. (B) Porção final do íleo (I), válvula íleo-cecal (IV) e ceco apresentando espessamento da mucosa. Há formação de dobras transversais dando aspecto cerebroide à mucosa. Linfonodos mesentéricos edematosos. A região medular apresenta áreas escuras e pequenos nódulos esbranquiçados estão presentes na cortical.

região medular e havia pequenos nódulos esbranquiçados na região cortical (Fig.2B). Nos demais órgãos não foram observadas alterações macroscópicas. Em quatro bovinos abatidos a porção final do íleo coletada no momento do abate estava espessada quando comparada à mucosa dos demais bovinos.

Histologicamente, nos bovinos necropsiados havia enterite granulomatosa caracterizada por infiltrado inflamatório composto principalmente por linfócitos, plasmócitos, macrófagos epitelioides e células gigantes tipo Langhans na lâmina própria da mucosa e na submucosa (Fig.3A). 0 infiltrado era difuso em todas as porções do intestino porém mais acentuado no jejuno, no íleo, no ceco, no cólon e no reto. Nestas áreas a mucosa estava espessada e observava-se acentuado infiltrado de macrófagos epitelioides que formavam ninhos principalmente na porção medial e no topo das vilosidades. No íleo estes macrófagos infiltravam toda a mucosa desde o topo das vilosidades até as criptas. Em algumas áreas da mucosa havia infiltrado difuso de linfócitos e macrófagos epitelioides predominantemente na porção apical e medial das vilosidades. Na submucosa o 


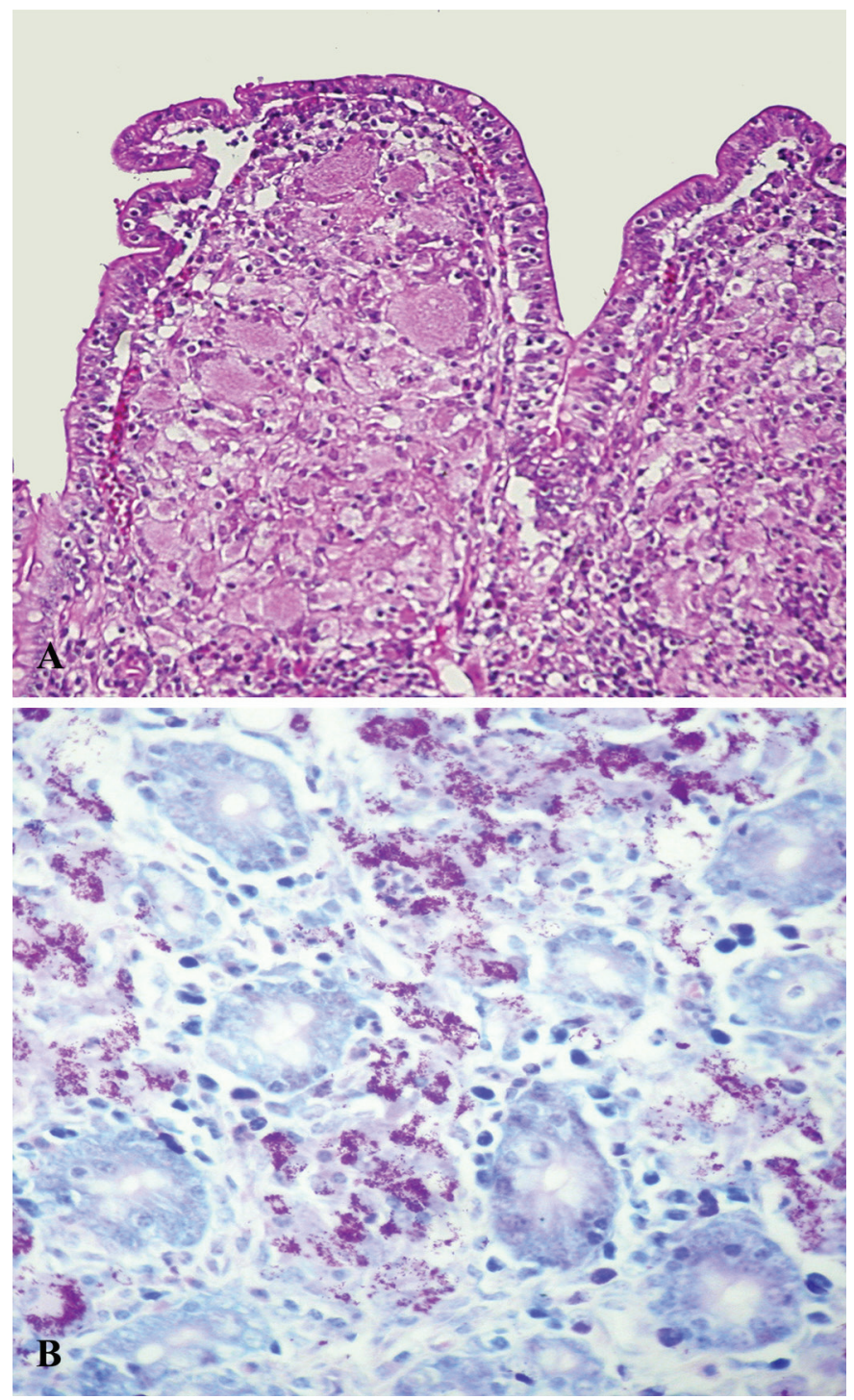

Fig.3. Paratuberculose em bovinos de corte. (A) Enterite granulomatosa difusa acentuada com presença de células gigantes tipo Langhans na mucosa do íleo. HE, obj.20x. (B) Mucosa do íleo com numerosos bacilos álcool-ácido resistentes. Ziehl-Neelsen, obj.40x).

infiltrado era difuso e em algumas áreas multifocal a coalescente. Havia, ainda, linfangite e adenite granulomatosa nos linfonodos mesentéricos observando-se acentuado infiltrado de macrófagos epitelioides e presença de algumas células gigantes tipo Langhans. No fígado havia discreto infiltrado inflamatório de células mononucleares distribuídos aleatoriamente pelo parênquima do órgão.

Pela coloração de ZN foram evidenciados numerosos BAAR no interior de macrófagos, de células gigantes, ou livres na mucosa e submucosa principalmente no jejuno, no íleo, no ceco, no reto e nos linfonodos mesentéricos (Fig.3B).

Na mucosa do íleo dos 34 bovinos abatidos em frigorífico havia, em dois casos, enterite eosinofílica e linfocítica difusa moderada com presença de células gigantes. Em outros sete bovinos havia enterite eosinofílica com presença de formas parasitárias compatíveis com Eimeria spp. Pela
Quadro 1. Material coletado e técnicas utilizadas no diagnóstico de um surto de paratuberculose no sul do Rio Grande do Sul

\begin{tabular}{lccc}
\hline \multirow{2}{*}{ Técnicas utilizadas } & \multicolumn{3}{c}{ Amostras coletadas (quantidade) } \\
\cline { 2 - 4 } & Necropsias (2) & Fezes (200) & Material de abate (34) \\
\hline HE $^{\mathrm{a}}$ & Positivo (2) & NR & Negativo (34) \\
ZN & Positivo (2) & NR & Negativo (34) \\
Cultura & NR & Negativo (40) & NR \\
PCR IS900 & NR & Positivo (5) & NR
\end{tabular}

${ }^{a} \mathrm{HE}=$ hematoxilina e eosina, $\mathrm{ZN}=$ Ziehl Neelsen, NR = não realizado; ${ }^{\mathrm{b}} \mathrm{a}$

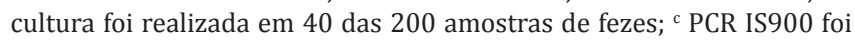
realizado em 34 das 40 amostras negativas na cultura.

coloração de ZN não foram evidenciados BAAR nestas amostras. Em 10 casos havia discreta enterite linfocítica difusa. Nos demais fragmentos de íleo coletados não foram observadas lesões significativas.

\section{Isolamento bacteriano e PCR IS900}

Das 40 amostras submetidas ao isolamento bacteriano em cultivo e não houve crescimento da bactéria após 24 semanas de incubação (Quadro 1). Das 34 amostras de fezes testadas na PCR, cinco amostras amplificaram a sequência genética IS900 específica do Mycobacterium avium subespécie paratuberculosis (Quadro 1).

\section{DISCUSSÃO}

Foi confirmada ocorrência da paratuberculose em um rebanho de corte no sul do Rio Grande do Sul pelos sinais clínicos, lesões macroscópicas e histológicas altamente sugestivas da doença e pela amplificação genética do agente etiológico.

Esta enfermidade tem sido diagnosticada preferencialmente em bovinos leiteiros em diversas regiões do Brasil (Yamasaki et al. 2013). No Mato Grosso do Sul (Riveira 1996) e no Pará (Silva 2005) em bovinos de corte, Map foi detectado por levantamentos sorológicos, não sendo mencionada a ocorrência da doença clínica nos rebanhos estudados. No Rio Grande do Sul, a paratuberculose foi descrita em bovinos e bubalinos, também, de exploração leiteira (Riet-Correa \& Driemeier 2007, Dalto et al. 2012), assim como em Pernambuco (Mota et al. 2010).

Por outro lado, em bovinos de corte os relatos da doença são escassos. Tem sido demonstrado que a paratuberculose é menos prevalente em bovinos de corte do que em bovinos de leite (Russel 2011). Um estudo conduzido pelo National Animal Health Monitoring System (NAHMS) dos Estados Unidos e publicado em 1997, revelou que 0,4 \% dos bovinos de corte eram positivos contra $2,5 \%$ de bovinos de leite positivos pelo teste de ELISA. Entre os rebanhos de corte testados 7,9\% tinham pelo menos um bovino positivo contra $21,8 \%$ de rebanhos de exploração leiteira com pelo menos um animal positivo (Russel 2011). Este autor afirma, por outro lado, que a prevalência da doença em bovinos de corte pode estar sendo subestimada em razão de estudos realizados em rebanhos auto selecionados com análises estatística com várias tendências e fontes de erro e soroprevalência não corrigida para a especificidade e sensibilidade dos testes utilizados. 
A menor prevalência da doença em bovinos criados extensivamente para a produção de carne pode ser, também, consequência do baixo número de casos clínicos nos rebanhos infectados o que leva ao desconhecimento da doença. Na região do presente estudo muitas vezes o diagnóstico laboratorial não é feito devido à realização de diagnóstico presuntivo de outras doenças que cursam com diarreia e emagrecimento progressivo como a intoxicação por Senecio spp. que é uma das mais importantes causas de morte de bovinos nesta região (Grecco et al. 2010, Karam et al. 2011).

No presente trabalho os bovinos eram nascidos e criados na propriedade, o que sugere a possibilidade da entrada do agente na propriedade pelos reprodutores adquiridos de outros locais para repasse para a inseminação artificial, ou pelo sêmen contaminado utilizado no rebanho. Apesar de a transmissão ocorrer principalmente pela rota oro-fecal a infecção congênita tem sido sugerida já que o agente tem sido cultivado do aparelho reprodutor tanto de machos como de fêmeas (Chiodini et al. 1984, Stabel 1998, Whittington \& Windsor 2009, Khol 2010). Embora a transmissão pelo sêmen não tenha sido confirmada, foi observado em um estudo a eliminação regular de MAP pelo sêmen. 0 contato direto ou indireto (inseminação artificial) com grande número de fêmeas susceptíveis sugere que os touros poderiam desempenhar importante papel na transmissão da doença (Khol 2010).

Os sinais clínicos de diarreia e emagrecimento progressivo nesta propriedade ocorreram em três bovinos de um total de 500, sendo que o primeiro caso com estes sinais havia sido observado três anos antes dos demais. Em estudos da descrição da doença em rebanhos leiteiros foi mencionada a ocorrência de oito bovinos afetados de um total de 345 bovinos (Driemeier et al. 1999), e cinco de um total de 250 vacas (Mota et al. 2010). No presente relato apenas $0,5 \%$ do rebanho apresentou sinais clínicos em um período de três anos. Em bovinos de leite é estimado que cerca de $10 \%$ dos animais em um rebanho infectado desenvolvem a doença clínica (Nielsen \& Toft 2008). Em animais de corte criados extensivamente a infecção é provavelmente menos frequente já que a possibilidade de contaminação pela rota oro-fecal é mais difícil. Isto poderia explicar porque a paratuberculose é mais diagnosticada em bovinos leiteiros, geralmente criados em confinamentos o que favoreceria a contaminação, principalmente pela via oro-fecal (Johnson-Ifearulundu \& Kaneene 1997, Radostitis et al. 2007).

Os bovinos necropsiados tinham dois e quatro anos de idade, respectivamente. Em uma revisão sobre a paratuberculose é mencionado que a doença clínica normalmente se desenvolve em animais com idades entre 2-5 anos (Clarcke 1997), embora sinais clínicos entre 5-8 anos (Yamasaki et al. 2010), entre 3-5 anos (Driemeier et al. 1999) e entre 4-5 anos (Mota et al. 2007) sejam, também mencionados. A infecção provavelmente ocorre antes do desmame, já que a maior suscetibilidade para a infecção em bovinos é em animais com menos de 30 dias de vida (Clarcke 1997, Sweeney 2011).

Devido à política de atuação do frigorífico os linfonodos mesentéricos não foram coletados durante o abate, não sendo possível a detecção de BAAR nestes órgãos. Em bovi- nos a descrição histológica detalhada está restrita às lesões moderadas ou acentuadas observadas na lâmina própria da mucosa intestinal (Gonzalez et al. 2005). Tem sido mencionado, no entanto, que granulomas focais nos linfonodos mesentéricos ocorrem somente nos estágios iniciais da doença apenas em casos experimentais em bezerros (Larsen et al. 1975). Por outro lado, BAAR foram detectados em linfonodos mesentéricos, também, em bovinos adultos (Balseiro et al. 2003) o que poderia sugerir que a coleta destes linfonodos auxiliaria na identificação de bovinos suspeitos de infecção pela detecção de BAAR.

No presente trabalho não houve crescimento bacteriano. De acordo com Whitlock \& Buergelt (1996) a eliminação do agente nas fezes é intermitente e a cepa de Map pode não se adaptar ao meio de cultura. Além disso, estes autores também mencionam a baixa sensibilidade da técnica como uma das causas do não crescimento de Map. A técnica, apesar disso, é considerada de referência no diagnóstico possuindo excelente especificidade, pois não proporciona resultados falsos positivos (Whitlock \& Buergelt 1996). A sensibilidade da cultura bacteriana nos estágios clínicos da paratuberculose pode chegar até $91 \%$, e variar de $45 \%$ a $72 \%$ nos casos subclínicos (Gilardoni et al. 2012). Em amostras fecais com baixa quantidade bacteriana apenas $15-25 \%$ dos casos são identificados por cultura (Whithlock \& Buergelt 1996).

De 34 amostras de fezes analisadas por PCR IS900, cinco $(14,7 \%)$ apresentaram amplificação do material genético de Map. A maior eficiência do PCR em tempo real em comparação ao cultivo bacteriano tem sido mencionada (Aly et al. 2010, Douarre et al. 2010, Carvalho et al. 2012), inclusive na análise de pools de amostras para estimar a situação da infecção em rebanhos de leite e, também, de corte, embora possam ocorrer falsos positivos e falsos negativos (Douarre et al. 2010).

No presente trabalho foi realizado o diagnóstico diferencial de enfermidades que cursam com emagrecimento progressivo e diarreia, tais como intoxicação por Senecio spp. cujo curso clínico é de 5-20 dias após o início dos sinais e frequentemente cursa com sinais neurológicos (Grecco et al. 2010). Nestes casos os bovinos deixam de se alimentar, o que não ocorre nos casos de paratuberculose e o curso clínico não é prolongado, embora alguns bovinos intoxicados possam sobreviver por alguns meses com os sinais de diarreia e perda de peso progressiva. Outra doença que pode ser confundida com paratuberculose é a tuberculose que raramente causa diarreia.

Estudos de prevalência dentro de rebanhos e entre rebanhos realizados nos Estados Unidos sugeriram que a paratuberculose afeta um substancial número de bovinos de corte naquele país, embora seja considerada como uma doença de bovinos de leite (Russel 2011). No Canadá foram encontradas prevalências de $0,8 \%$ e 1,5\% entre bovinos e $15,2 \%$ e $28,5 \%$ entre rebanhos de corte com pelo menos um teste positivo (Waldner et al. 2002).

\section{CONCLUSÕES}

Pode-se concluir que a paratuberculose apesar dos poucos relatos ocorre, também, em bovinos de corte criados 
extensivamente no sul do Rio Grande do Sul e pode ter uma prevalência maior do que se supõe na região.

Alerta-se para a necessidade do diagnóstico e da tomada de medidas efetivas de controle para esta doença que, por muitos, ainda é considerada uma doença exótica no Brasil.

\section{REFERÊNCIAS}

Aly S.S., Mangold B.L., Whitlock R.H., Sweeney R.W., Anderson R.J., Jiang J., Schukken Y.H., Hoving E., Wolfgang D., VanKessel J.A., Karns J.S., Lombard J.E., Smith J.M. \& Gardner I.A. 2010. Correlation between Herrold egg yolk medium culture and real-time quantitative polymerase chain reaction results for Mycobacteruim avium subsp. paratuberculosis in pooled fecal and environmental samples. J. Vet. Diagn. Invest. 22(5):677-683.

Balseiro A., Prieto J.M., Espi A., Pérez V. \& Garcia Marín J.F. 2003. Presence of focal and multifocal paratuberculosis lesions in mesenteric linph nodes and ileocecal valve of cattle positive to the tuberculin skin test. Vet. J. 166:210-212.

Begg D.J. \& Whittington R.J. 2008. Experimental animal infection models for Johne's disease, an infectious enteropathy caused by Mycobacterium avium subesp. paratuberculosis. Vet. J. 176:129-145.

Carvalho I.A., Silva V.O., Vidigal P.M.P., Silva-Júnior A. \& Moreira M.A.S. 2012. Genetic evalution of IS900 partial sequence of Mycobacteruim avium subesp. paratuberculosis Brazilian isolates from bovine milk. Trop. Anim. Health Prod. S11250-012-0117-1. (Online)

Chiodini R.J., VanKruiningen H.J. \& Merkal R.S. 1984. Ruminant paratuberculosis (Johne's disease): The current status and future prospects. Cornell Vet. 74:218-262.

Clarke C.J. 1997. The pathology and Patogenesis of Paratuberculosis in Ruminants and Other Species. J. Comp. Pathol. 116:217-261.

Dalto A.C., Bandarra P.M., Pavarini S.P., Boabaid F.M., Bitencourt A.P.G., Gomes M.P., Chies J., Driemeier D. \& Cruz C.E.F. 2012. Clinical and pathological insights into Johne's disease in buffaloes. Trop. Anim. Health Prod. 44:1-5

Driemeier D., Cruz C.E.F., Gomes M.J.P., Corbellini L.G., Loretti A.P. \& Colodel E.M. 1999. Aspectos clínicos e patológicos da paratuberculose em bovinos no Rio Grande do Sul. Pesq. Vet. Bras. 19(3/4):109-115.

Douarre P.E., Cashman W., Buckley J., Coffey A. \& O’Mahony J.M. 2010. Isolation and detection of Mycobacterium avium subesp. paratuberculosis (MAP) from cattle in Ireland using both tradicional culture and molecular based methods. Gut Pathol. 2:11-17.

Gilardoni L.R., Paolicchi F.A. \& Mundo S.L. 2012. Bovine paratuberculosis: a review of the advantages and disadvantages of different diagnostic tests. Revta Argent. Microbiol. 44:201-215.

Gonzalez J., Geijo M.V., García-Pariente C., Verna A., Corpa J.M., Reyes L.E., Ferreras M.C., Juste R.A., Garcia Matín J.F. \& Pérez V. 2005. Histopathological classification of lesions associated with natural paratuberculosis infection in cattle. J. Comp. Pathol. 133:184-196.

Grecco F.B., Schild A.L., Estima-Silva P., Marcolongo-Pereira C., Soares M.P. \& Sallis E.S.V. 2010. Aspectos epidemiológicos e padrões de lesões hepáticas em 35 surtos de intoxicação por Senecio spp. em bovinos no sul do Rio Grande do Sul. Pesq. Vet. Bras. 30(5):389-397.

Huchzermeyer H.F.A.K. 1994. Paratuberculosis, p.1445-1457. In: Coetzer J.A.W., Thomson D.R. \& Tustin R.C. (Eds), Infectious Diseases of Livestock with Special Reference to Southern Africa. Oxford University Press, Cape Town

Johnson-Ifearulundu Y.J. \& Kaneene J.B. 1997. Relationship between soil type and Mycobacterium paratuberculosis. J. Am. Vet. Med. Assoc. 210(12):735-740.

Karam F.C., Schild A.L. \& Mello J.R.B. 2011. Intoxicação por Senecio spp. em bovinos no Rio Grande do Sul: condições ambientais favoráveis e medidas de controle. Pesq. Vet. Bras. 31(7):603-609.
Khol J.L., Kralik P., Beran V., Aurich C., Baumgartner W. \& Pavlik I. 2010. Consecutive excretion of Mycobacteruim avium subesp. paratuberculosis in semen os a breeding bull compared to the distribuition in feces, tissue and blood by IS900 and F57 quantitative real time PCR and culture examinations. J. Vet. Med. Sci. 72(10):1283-1288.

Klanikova B., Slana I., Roubal P., Pavlik I. \& Kralik P. 2012. Mycobacterium avium subsp. paratuberculosis survival during fermentation of soured milk products detected by culture and quantitative real time PCR methods. Int. J. Food Microbiol. 157(2):150-155.

Larsen A.B., Merkal R.S. \& Cutlip R.C. 1975. Age of cattle as related to resistence to infection with Mycobacterium paratuberculosis. Am. J. Vet. Res. 5:255-257.

Mota R.A., Pinheiro-Junior J.W., Gomes M.J.P., Peixoto R.M., Maia C.L., Brito M.F., Chies J.A.B., Snel G.G.M., Bercht S. \& Juffo G.D. 2007. Paratuberculose em um rebanho leiteiro no Estado de Pernambuco, PE. Arqs Inst. Biológico, São Paulo, 74(2):73-79.

Mota R.A., Peixoto P.V., Yamasaki E.M., Medeiros E.S., Costa M.M., Peixoto R.M. \& Brito M.F. 2010. Ocorrência de paratuberculose em búfalos ( $\mathrm{Bu}$ balus bubalis) em Pernambuco. Pesq. Vet. Bras. 30(3):237-242.

Nielsen S.S. \& Toft N. 2008. Ante morten diagnosis of paratuberculosis: a review of accuracies of ELISA, interferon g assay ad fecal culture techniques. Vet. Microbiol. 129:217-235.

Radostits O.M., Gay C.C., Hinchcliff K.W. \& Constable P.D. 2007. Veterinary Medicine: a textbook of the diseases of cattle, horses,s heep, pigs and goats. 10th ed. Saunders Elsevier, Philadelphia, p.132-137.

Riet-Correa F. \& Driemeier D. 2007. Paratuberculose, p.407-414. In: Riet-Correa F., Schild A.L., Lemos R.A.A. \& Borges J.R.J. (Eds), Doenças de Ruminantes e Equinos. Vol.1. 3a ed. Pallotti, Santa Maria, RS.

Riveira F.E.B. 1996. Levantamento sorológico utilizando-se a técnica ELISA em rebanhos apresentando problemas reprodutivos. I. Enterite paratuberculose. Anais Encontro de Laboratórios de Diagnóstico Veterinário do Cone Sul. Campo Grande, MS, p.20-22.

Russel A.J. 2011. Control of paratuberculosis in beef cattle. Vet. Clin. Food Anim. 27:593-598.

Silva E.B. 2005. Diagnóstico de paratuberculose em bovinos de corte do estado do Pará-Brasil. Dissertação de Mestrado em Ciência Animal, Universidade Federal do Pará, Castanhal, PA. 60p.

Sweeney R.W. 2011. Pathogenesis of paratuberculosis. Vet. Clin. Food Anim. 27:537-546.

Stabel J.R. 1998. Johne's: a hidden threat. J. Dairy Sci. 81:283-288.

Tiwari A., Vanleeuwen J.A., McKenna S.L.B., Keefe G.P. \& Barkema H.W. 2006. Johne's disease in Canada. Part I. Clinical symptoms, pathophysiology, diagnosis, and prevalence in dairy herds. Can. Vet. J. 47:874-882.

Waldner C.L, Cunningham G.L., Janzen E.D. \& Campbell J.R. 2002. Survey of Mycobacterium avium subspecies paratuberculosis serological status in beef herds on community pastures in Saskatchewan. Can. Vet. J. 43(7):542-546.

Whitlock R.H. \& Buergelt C. 1996. Preclinical and clinical manifestations of paratubeculosis (including pathology). Vet. Clin. North Am., Food Anim. Pract. 12(2):345-357.

Whittington R.J. \& Windsor P.A. 2009. In utero infection of cattle with Mycobacterium avium subsp. paratuberculosis: a critical review and meta-analysis. Vet. J. 19(1):60-69.

Yamasaki E.M., Tokarnia C.H., Galvão A., Gomes M.J.P., Chies J.A.B., Veit T.D., Aragão A.P. \& Brito M.F. 2010. Aspectos clínico patológicos e controle da paratuberculose em rebanho bovino leiteiro. Pesq. Vet. Bras. 30(11):911-932.

Yamasaki E.M., Brito M.F., Mota R.A., McIntosh D. \& Tokarnia C.H. 2013. Paratuberculose em ruminantes no Brasil. Pesq. Vet. Bras. 33(2):127140. 